\title{
Nigerian Media and Indigenous Cultures Transformation: The Journey So Far
}

\author{
Robert Odey Simon ${ }^{1 *}$ and Besong Eric Ndoma ${ }^{2}$ \\ ${ }^{1}$ New Frontier Industries Ltd, Nigeria \\ ${ }^{2}$ Department of Philosophy, Federal University, Nigeria
}

\begin{abstract}
The Nigerian mass media owe their Nigerian peoples the duty of transforming their diverse cultures respectively. Although the task seems thankless and complex, it is indeed rewarding, thankful, worthwhile, easy and simple if willing, committed and functional. The current worrisome state of our indigenous cultures is majorly because the media, that are suppose to duly rouse the peoples to their cultures and generally effect the transformation of these cultures, have simply abandoned their right roles in doing so for the otherwise. Rather, they have resorted to attrition and westernisation, dabbing them variously. This paper calls on Nigerian media to turn a new leave and take up active indigenous cultures transformation roles. Government, schools, parents (families), religious groups, corporate organisations and every individual must all actively join hands with the mass media in their new efforts and roles to transform our cultures. The paper basically draws from relevant library print sources, besides intuition and observation primary sources. The text content analysis, the descriptive method and qualitative comparative and analytical approaches ground the study.
\end{abstract}

Keywords: Nigeria; Media; Indigenous cultures; Transformation

\section{Introduction}

An objective deep scholarly and professional introspection and retrospection would simply prove to one the extent, outcome and reality of the journey the Nigerian media have had so far in the transformation of indigenous cultures. The journey is full of odds from these media to these cultures and their peoples. The media, on their part, have not been having it lightly from the government and the hostile westernised globalised new world, with its more overwhelming negative trends and effects. The journey seems not to be a bird of roses. It is characterised with mixed adventures: the good, the bad and the ugly; positive and negative; indigenous and western; smooth, rough and rugged; upgrading and degenerating; constrained and free if willing; aided and unaided; and solely and massively.

Ajala notes, the mass media encourage and ginger people to achieve the aims or goals of the society. These goals are promoted by the media, which then stimulate and foster the aspirations and activities of individuals and communities to achieve such goals [1].

Chiakaan and Ahmad observe that national development and sustenance can only be realised where the media are positively effective in their operations. Where they are not, they can rather cause underdevelopment in the society. This indeed is what they are currently causing in Nigeria, particularly in the rural societies, including failing to rouse the attention to and interest of the people in indigenous arts and cultures. Chiakaan and Ahmad [2] further note that often, the activities of the mass media in a society, especially Nigeria, are never perfect. They are characterised by sensationalism, violence, crime, sectionalism, inaccurate presentation of issues, pollution of culture and so on, which are highly anti-development [2].

Sambe [3] refers to these roles of the press as narcotizing dysfunctional roles. For example, the media expose both adults and children to violence on television screen and cause commotion with sensational and inaccurate broadcast reports and programmes. Research has proven that most children who are exposed to violence on television screen are more prone to violent or aggressive behaviour when they grow into adult hood [2-4]. Instead of promoting and developing our indigenous culture, arts, technology, enterprises and lot others, our media resort to their relegation for Western culture mimicry, dabbing ours as being barbaric, obsolete, local, native, traditional, fetish and what have you $[2,5,6]$.

Mass media also play several other vital functions, some of which are their core functions. Uyo articulates the various contributions of scholars on what constitute the functions of the mass media and arranged them into the acronym: PENNIES- persuasion, education, news, information interpretation, selling and entertainment. In explaining each of the functions, emphasis is placed particularly on the primary mass media message (a newspaper articles, radio or TV programmes) [7], designed to achieve one aim or the other, since it is possible for a message to perform more than one or two functions at a time [8]. Persuasion describes the mass media messages that are designed primarily to convince or convert the audience through valid convincing debates. The education role describes the messages designed primarily to instruct the audience, which involves educational broadcasting/ journalism, when the masses are kept abreast of happenings via such messages and programmes designed to enrich the knowledge of the audience. Interpretation involves explaining salient issues, problems and matters of public concern by the media to the audience on already known events. Selling involves marketing and advertisement roles of the media that involve inducing or convincing their audience, the masses, to buy a given product. And, the entertainment role of the media is that of amusement and leisure for the public.

*Corresponding author: Simon OR, New Frontier Industries Ltd, 2nd Floor, Ashby Investment House, 7 New Bridge/Otukpo Road, Makurdi, Benue State; Bridge Gate Research Consult Ltd, Abraka, Delta, Port-Harcourt, Rivers, Nigeria, Tel: +2348030410087; E-mail: greatbob1st@gmail.com

Received October 26, 2016; Accepted November 07, 2016; Published November 14,2016

Citation: Robert OS and Besong EN (2016) Nigerian Media and Indigenous Cultures Transformation: The Journey So Far. J Mass Communicat Journalism 6 : 317. doi: 10.4172/2165-7912.1000317

Copyright: (c) 2016 Simon RO, et al. This is an open-access article distributed under the terms of the Creative Commons Attribution License, which permits unrestricted use, distribution, and reproduction in any medium, provided the original author and source are credited. 
Lamenting on the gross abuse, negligence and relegation of virtually all aspects of our African indigenous culture by ourselves too, which is basically because of the negative role played by our media, Prah observes, too often, culture is understood in Africa to mean old practices, especially of the display-type like traditional dance, music and singing, arts and the like. Such attributes and artefacts are reified and stylised recollections, which are said to typify African culture. In other words, African [Nigerian] cultures tend to be regarded as museum pieces, arrested and fossil in time. They invariably are displayed more in response to western taste for African exotica than a revival, renewal or reaffirmation of the African heritage [6]. For example, since Picasso and the Cubists historically decontextualised, African traditional art has been regarded in Western circles as a revitalising stimulus for jaded Western artistic genre. What is depressing about this is that some African [Nigerian] artists latch on to such western fads as avant-garde representations which should be automatic universal appeals.

\section{The Concepts of Culture and Media}

Isa [9] in Yusuff notes that the concepts 'culture' and 'the media' are interrelated. As culture is sustained through the media, so the latter needs cultural atmosphere to fruitfully operate. He adds that the love of one's race and culture (i.e., patriotism) considered in itself, is good and necessary for the survival of both race and its culture. By the foregoing, Isa's view reflects the relationship between Nigerian media and cultures and points to the need for cultural patriotism by the media, which can widely spread to the entire Nigerian masses, their audience, who often tend to or are very willing to absorb anything given maximum attention by the media. Isa in Yusuff [7] thus submits that as such, for there to be any meaningful development in any society, both the electronic and print media must play fundamental roles [9].

According to Isa in Yusuff, African culture for instance, designates three types of cultural traditions which express originality of cultural traits native to such specific cultural area. These are cultural autochthony, which shows original traits; cultural amnesia that reveals a process of inter cultural and inter sub-cultural exchange and accretion of values and thoughts; and certainty which shows the migration of culture in secondary and tertiary degrees [rates]. He further puts it viz: The level of cultural amnesia which involves exchange and accretion of values and thought becomes the central point of fundamental relation between culture and the media. And since the media refers [sic] to any agency that functions for the articulation and dissemination of ideas and information in order to influence an audience or institutions, the media therefore becomes the major instrument for the growth and propagation of culture in any society [9].

Isa's view is apt, empirical and lent credence to the fact that the transformation of indigenous cultures can best be done by the media, once they are active, operational (functional), willing, well mobilised and supported duly. It is thus quite regrettable and worrisome that Nigerian media are doing little or nothing as to the transformation of the indigenous cultures that characterise Nigeria. First, most media practitioners are bent to western culture cum westernisation and globalisation trends of relegating, battering, damming and endangering anything indigenous. Next, following their reluctance and nonchalance, there seems to be a hostile, rough, un-enabling environment, within which they are carried away. They lack enough support from government, local and international, various societal institutions and individuals. The globalised village is also hostile to anything Nigerian, African and Black. And the Nigerian press now joins 'the moving train' un-sceptically, in naivety, believing and showing that western culture mimicry and promotion is the ultimate. Lastly, most of the press tend to misunderstand and misuse the positive globalisation trends and offers with which they should ordinarily apply effectively to develop, rebrand and transform their own cultures. They fail to blend their indigenous Nigerian/African culture with that of the West.

\section{The Journey of Nigerian Mass Media}

Although from time immemorial, Nigeria with her diverse nations, peoples or cultures has had various mass media, which are now often described 'traditional', 'local' or 'native' mass media, the formal media of western build came with colonialism. Then, drums, gongs, clappers, whistles, artefacts, horns, stones tablets, scrolls, calabash, etc. were all used for public/group information dissemination and reception. In Yoruba pre-colonial administration, for instance, a defaulting Oba was usually shown a calabash and thus rid of, dethroned. Isa in Yusuff lends credence to this fact when he says, 'Within the old Yoruba, Benin and Igbo kingdoms, rulers, on many occasions had been overthrown by the collective actions of the people, mobilised by the drummers and town criers. In the Northern part of Nigeria, Arabic writing was in vogue before the advent of colonialism and it was a means of communication or information that existed in various ethnic groups and kingdoms [9]

The formal mass media in Nigeria is traced to Rev. Henry Townsend in 1859, who first began the publication of the 'Iwe Irohin', published by missionaries whose main aim was to influence the traditional government they found in Egbaland, whose mode of operation did not tally with their theocracy; and educate their Nigerians 'converts' by being taught how to read and write so as to spread, promote and assimilate the religious culture in contact. Next was Richard Blasé who came to Nigeria with the idea of how to use newspaper to mobilise the masses against the colonialists, as was the case of anti-colonialism via his newspaper in Sierra-Leon. Blase and his followers introduced the use of adversarial journalism against the colonialists, which was abruptly absorbed by the ex-slaves who returned home.

Nnamdi Azikiwe made the first breakthrough in beginning a popular indigenous newspaper, with readership of national scope/ wide patronage. His 'Western African Pilot', founded in 1939, was the first mass circulation newspaper devoted to promoting serious wide scope anti-colonial mobilisation- nationalism-in Nigeria [9]. Despite Herbert Macauley's 'Daily Times' of 1926, being a major nationalism weapon, it lacked the credibility of Azikiwe's. The paper articulates a lot on some national issues but was not a crusading newspaper. For the Hausa-speaking people in Northern Nigeria, 'Gaskiya Tafi Kwabo', a vernacular newspaper, was set up in the 1930's by the Colonial Development Corporations. The 'Nigerian Citizen' of the '40's and the 'New Nigeria' in Kaduna were set up mainly for Nortern interest. "The creation of the 'New Nigeria' was a political act," said Charles Sharp, a British businessman employed by the Northern regional government to establish it.

The 1951 political events, in which Awolowo's Action Group manoeuvred Azikiwe with his NCNC, caused a division between politics and the media and culture, as media became regionalised. From then onward, series of region-centred and sentiments spread sporadically with ethno-religious and regional journalism. In the words of Isa in Yusuff [9], "Thus, this divisive cry of 'To thy tents Oh Israel' sounded in 1951, has remained with the Nigerian press till date." The regionalisation of the media was later followed by propaganda which became pronounced during the civil war. These brought extreme government control of the media, print and electronic alike, right from the first electronic media established in Lagos, Radio Vision Services, radio and later television. Against the foregoing backdrop, the culture task (role) of the media was abandoned. 
This press shift and unfulfilled obligation make their existence insignificant and their constitutional roles a mere political act, a mere paper stipulation: The press, radio, television and other agencies of the mass media shall at all times be free to uphold the fundamental objectives and highlight the responsibility and accountability of government to the people (Sec. 21, 22, 38 of 1979, 1989, 1999 Constitutions of Nigeria respectively). Their core function which they always boast of now is entertainment. But it is full of western contents. To this end, Obasanjo [10] describe mass media as any agency, modern or traditional, that operates for the articulation and dissemination of ideas and information, generally with the intent to influence or control an audience or the institution that constitutes legalized power and authority. Unfortunately, Nigerian media have no influence on government, the legalized power and authority, and negative influence on their Nigerian populace, audience and cultures.

Anyaegbunam in Yusuff [11] writes ...In this bizarre cultural dissonance among the Nigerian citizens, Nigeria and the global culture...We [media practitioners] share some of the blame. ...What has not been canvassed however is why four decades after colonialism and self rule (military or civilian), journalists in Nigeria still practice with the same sense of alienation. The intensity of it suggests that beyond the nature of governance is a profound need to reorient at the media towards the new trends in the world.

\section{Nigerian Media and the Indigenous Cultures}

Our Nigerian and African cultures with all their embodiments are being incessantly polluted and westernised by our mass media, which have rather resorted to Eurocentric prejudicing journalism/ broadcasting, like the western scholars/artists of such rendition. Chiakaan and Ahmed [2] say the pollution is a product of pornographic films or programes on television and pictures in newspapers, magazines and internet. It was an abomination for Nigerian females to appear in jeans or trousers generally. Nowadays, they do not only appear in jeans trousers but do so sensationally by leaving bare the most sensitive parts of their bodies. Our higher institutions are among common places where this unfortunate uncultured act of immodesty is mostly practised.

Allimi [12] laments, when you therefore take a global look at the communication channels operating in Nigeria today, there seems to be a successful imposition of alien values, alien faith and alien psychology on our culture. Why should this be so? On radio and television and in the press, both privately owned and public owned, we are devoting space and airtime to foreign "non-creative works" which to me [him] is a curious misapplication of valuable communication resource. For instance, must we further the maddening consumption of musical works of foreign artistes on our airwaves ...foreign artists whom we owe such obligation? Don't let's deceive ourselves. No one says he is giving the public what it wants unless the public knows the whole range of possibilities which the medium can offer and from this range chooses what it wants... Usually if people say they know what they like, it does not always mean they know.

Further, the over promotion of foreign culture in Nigeria has not only relegated, raped and underdeveloped our indigenous cultures, many Nigerians', especially the youths', interest in their God-given heritage- culture- has been forcefully and abruptly killed. Western culture mimicry has become the order of the day. For a show-off, most Nigerian elitist and common parents alike now resort to teaching their children and wards English, the official/media language, leaving them with no cultural identity as they can only poorly speak or/and write the Second Language, L2, but could barely say a word in their mothertongue. Anything indigenous is old-school, barbaric, archaic and local and so on. It is now common to see a Nigerian in suit in a hot day on the street. They imitate this without realising that most Whites go in suit and regalia because of their cold frizzing environments. Accent is linguistic group- specific, as idiolect is to every individual, but for 'phone' or 'fone', most Nigerians, particularly the press who can rarely speak phonetically or good English, mispronounce e.g. edge /ed3/ for urge /3:d3/: The governor edge, instead of urge... Anyaegbunam in Yusuff [11] notes, 'A citizen with the right culture and attitude towards Nigeria, who is not a potential monster like many of us, would not get into government to loot, plunder and inflict limitless hardship on the rest.'

According to Tony Momoh, 'a culturally aware person has won more than half of his battle for liberation'. He further states:Freedom is meaningless without cultural foundation as its springboard. There are not one people who neglected or compromised their culture that did not sink into oblivion. Depend on others and do things of their point of view and you are finished because you are an imitator, a cipher, and nothing worthy can emerge from within your being [11].

Tony Momoh adds that "Lomo Kenyatta summarized it all when he said, 'The British came, gave us the Bible and took our land'. To Momoh's words, Ngozi Anyagbunam adds, 'They have come again in the $21^{\text {st }}$ century, but this time, they gave us some dollars and made us their parrots [11]. And, of course, the mass media (the press) are the lead parrots of neo-colonialism that is sporadically eroding our indigenous cultures and all their embodiments.

Writing on 'Television and Challenge of Culture', Emmanuel Obiechina laments that Africa's tragedy had always been that of a continent battered away on itrifles in the cultural unity of the Nigerian people. This exploitation of the wealth of the colony for the benefit of his home country has the unfortunate effect of assimilating him from his indigenous culture. Fortunately, the assimilation was only halfhearted and haphazard and therefore unsuccessful; the unhinging from tradition was also far from complete. The phenomenon has given the westernised Nigerian the character of a Mongrel; he is only half westerner and half an indigene. The greatest mistake to avoid is to define Nigeria's national culture in terms of the culture of the elite.

Robert and Dibie [5] write, The Nigerian mass media, over whelmed by colonial-western-majority mentality, preach the sermon of gross negligence for a digression from Nigerian cultures, as only the obvious social aspects of the claimed major cultural groups are blended with the adopted Western. This is very pathetic and unfortunate. Although the cultural policy for Nigeria advocates 'effective use of the press, radio, television and film for protecting Nigeria's cultural image and aspiration', the reverse is unfortunately the case, as little or nothing is yet reckoned with from the press in promoting Nigeria's cultural image, aspiration and development, thereby, heading towards wiping Nigerian cultures.

\section{The Media and Indigenous Cultures Transformation}

By developing and promoting indigenous cultures rather than the current attrition and westernisation gestures of the mass media, these cultures would be transformed. First, the orientation of the media must change. The press must insist on at least a minimum standard of integrity, a minimum standard of decency from all 'Nigerians: our leaders in government, military, politics, media, commerce, business, professionals, traditional rulers and the citizenry [12]. Allimi in Yusuff 
notes,Cultural journalists must be the vanguard for portraying our good cultural values and societal norms to our children especially through relevant art, music, dance, drama and sports. Let us use all the components of our art and culture to show that hard work and honesty pay [12]. The family system, the most effective instrument of public education, the core of any nation, must not be left out. Your role is that of social mobiliser, championing the cause of development and the promotion of societal values and norms. Dear colleagues [the press], we need to develop Nigeria and Nigerians, the perception of being a Nigerian of Nigerianness. We must, as apostles of cultural journalism, champion the culture of tolerance and accommodations of our tradition. The media must preach this cultural value to both our civil and military leaders and Nigerians in general.

Further, on the socialisation role of the mass media, Moemeka writes, The mass media help unify society and increase social cohesion by holding and teaching a broad base of common social norms, values, and collective experience. Through this activity, the mass media help transmit culture from generation to generation. Social norms, values and culture in general have become topics for conscious education by the mass media through the formal school system.

The mass media are also seen as playing the role of motivating and mobilising people to attain their goals politically, socially and economically as individuals and collective members of the society, which they do with some consideration of certain vital elements for sustainable national development [1,2]. The mass media ought to promote and sustain indigenous cultures through publicity. But unfortunately, Nigerian mass media are yet to deliver significantly in this area. Belch and Belch describe publicity thus: Publicity refers to non-personal communications regarding an organisation, product, service or idea not directly paid for or run under identified sponsorship. It usually comes in the form of a news story, editorial or announcement about an organization and/or its products and services.

The mass media, both print and electronic, as institutions, socialisation agents and part and parcel of the Nigerian society, must continue to play their part in order to ensure that development is realised and sustained. This is the view of the structural-functionalists, who refer to 'structure' as 'part of a whole' and 'function' as 'effect', and thus emphasis is laid on media impact or influence on society [13].

Many literary artists have done better than the press in promoting and transforming our indigenous cultures, such as recreating them, treating the image-battering wounds and pains inflicted on Africa/ Nigeria and their peoples and systems, with falsehoods and prejudices by the colonialists, their writers and artists as well as indigenous (African) writers and artists of prejudicing Western perspectives, the Western imitators. When in the 70's and 80's, some African writers like Chinua Achebe, Ngugi Wa Thiongo, Wole Soyinka, Ahmed Yerima, Esiaba Ironi, Niyi Osundare, the Amalis, Julius Nyerere, Nkrummah, among others, fought the Eurocentric prejudicing rendition of western critics as assessing their works by the so-called 'universal standard', they were merely warding off the harbinger of the present full scale assault by the cable and satellite stations [12].

Journalists must be visionary and original (indigenous) and face the realities of their core existence, environment and society, with which they can unite their peoples, give them a sense of identity, purpose and direction, and develop as well as rouse the peoples to develop their cultures, assets and systems. Anyaegbunam in Yusuff (2005:44) maintains that these can only be best done by the local (indigenous) journalists. Where such issues are left to lie dormant, other issues that are extra-cultural, with the impetus and spontaneity of technology easily fill the vacuum. Thus, rather than the mere task of sourcing issues, it becomes a tougher battle of dislodging an alien issue or at least modifying it to suit the local sensibility.

According to Angaegbunam in Yusuff [11], our journalists can start by looking at our 400 -year old culture of inferiority complex in the face, ugly as it looks, and address it. After that, we will be imbued with the necessary insight to redefine certain high issues from democracy, population, environment, war, peace, poverty, womanhood to language to suit our peculiar situations in Nigeria and Africa. To understand one's culture, their history must not be left behind, thrown away or disregarded. Journalists and all Nigerians alike must be properly enlightened and educated regularly by schools, appropriate institutions/authorities, agencies and the media on indigenous cultures and history. The National Institute for Cultural Orientation (NICO) is one such body to so-enlighten the press.

Information managers, processors, experts and disseminators must constantly get training that would spur them up and rouse them to becoming more and more familiar with their background, peoples, and those phenomena and characteristics they often tend to neglect, abuse and pay little or no attention to so as to deeply analyse, develop, promote and transform them. Otherwise, when the press continuously allow their minds to be overwhelmed or completely cluttered by external (alien) cosmology, orientation and ideologies, they would always view the other people's world as superior to or better than theirs in all ramifications, thus relegating, battering and underdeveloping theirs, our indigenous cultures, instead of blending the two cultures in contact for a balanced transformation. As people and socialisation agents with heterogeneous audience who rely mostly on them, the negative role (self-immolation) of the media translates and transfers monumentally to more than half and one quarter of the whole population of the nation, Nigeria [11].

The media should greatly and constantly assist in providing the medium for transmitting knowledge and education of our culture to the populace. While functioning as an agent of mobilisation, the media should set an agenda for priorities within our culture, which translate into consciousness for popular participation and indeed a proper democratic culture. They should ensure a deep sense of objectivity, ethics, truth and respect for our culture(s) in their news and programmes. They must be mindful of what they receive from foreign media and spread about and to us. According to Isa in Yusuff [9], in every culture, there are certain characteristics or traits which no matter how the culture changes, still remain very important. It is the role of the media to identify these aspects of the culture and emphasise them to the people, to preserve, maintain and uphold. The media should encourage government to set up institutions that would ensure the promotion of our culture.

Those aspects of our culture that are autochthonous, for example, languages, arts, dressing, kinship, marriage, festivals, etc. should be promoted. Nothing interests the people so much like seeing their indigenous activities and ways of life broadcast and showcased in the mass media. Isa [9] posits that the moment the different ethnic groups in Nigeria begin to appreciate their various cultures to such an extent that such cultures receive media coverage, it would be very easy for the nation to adopt, develop or evolve a national culture. And, by so doing, these cultures would have been transformed.

\section{Related Literature on Manifestations and Effects of Westernisation on Indigenous Cultures}

According to Robert, Besong and Dibie [14], it is quite pitiable, 
unfortunate and regrettable that our esteemed norms, values and cultures of Africa are still being eroded by Africans themselves along with the colonialists and neo-colonialists, Africans' high intellectual prowess and talents notwithstanding. Africans had been and are still being brainwashed by both white and black elites and academics alike. Robert, Besong and Dibie [14] further lament, Robert and Dibie [14] had lamented on the above likewise. They maintain, among others, that the literacy level of our children, most especially those of the elite, intellectuals/academics and the bourgeoisies, is not proven by stripping them off of their indigenous language, their Africanness. Amidst all that, our education is still struggling to gain standard and recognition, as it continuously decline, beleaguered by various serious issues like poorly trained and motivated personnel, corruption, cultism, exam malpractice, indiscipline, moral decadence, parental irresponsibility, failed elites and bad governance, negative acts of the mass media, theoretical-based education, lack of infrastructure and good learning environment, etc.

Ndimele in Orru [15] descries the situation thus: For more than a half century, African nations have been battling with the imposition of non-indigenous African languages on the educational system and the situation had been aggravated by globalization and the overwhelming presence of the imperial languages in the ICTs. African languages and their native speakers live in a more intense and harsh linguistic environment, as access to information is one through imperial languages. One third of African languages will die before [by] the first quarter of this century as the domains of use of the languages continue to reduce.

According to Arowolo, the trend of cultural westernisation of Africa has become very pervasive and prevalent, such that Western civilisation has taken precedence over African values and culture and the latter is regarded as inferior to the former. As with other societies and cultures in the so-called Third World, the impact of Western civilisation on Africa has occasioned disunity in forms of life throughout the continent. This has led to cultural dualism that often presents itself as a real dilemma in concrete real life situations. African traditional values have undergone and still undergo culture change and acculturation, which affect social relationships, behaviour, systems and all human endeavours in contemporary Nigeria and Africa at large.

Nwauzor [16] observes that changing values affect the ideological bases of a society. The changing values, norms and culture of Nigerian society is greatly affecting it and greatly accounts for its ageing underdevelopment and national issues, besides the lasting effects of colonialism. Prah [2] observes that 'the post-colonial African elites have failed or seem to lack the ability, if not zeal, to provide the sort of leadership needed to improve the quality of life of the teeming masses of African humanity'. Gyekye as cited by Lassiter maintains thus: cultural values and practices of traditional Africa can be considered positive features of the culture and can be accommodated in the scheme of African modernity, even if they must undergo some refinement and pruning to become fully harmonious with the spirit of modernity and to function satisfactorily within that culture. Allimi [12] observes, our media must promote primarily Nigeria's indigenous music, our sports and arts, culture and much more. We need our music, we need radio and television programmes, we need features and essays that uplift the spirit that uplift life. But then in Nigeria, we value things alien, not for their relevance to our lives but simply because of their foreignness. Is it not unfortunate that most video movies produced by our own producers and directors celebrate violence and immorality which corrupt our values and cultural norms? Why must we promote prostitution as being creative? Take Guns! Guns in video movies and films don't kill. But guns on the streets and in the hands of evil men do kill. Bad, violent language, fetish content of video movies, dirty clothing, fetish beliefs, page 3 girls are not cultural. These have led to our Nigerian actors and actresses being bad role models in our society... especially to our children. We must also frown at the emerging trend of the preference of advertisers for foreign programmes, especially on television and FM stations nationwide devoting over $80 \%$ of their airtime to the promotion of foreign music.

These uncultured traits, dispositions and rhetoric's are rapidly learnt and diffused by our children, then hatching millions of odds into our blessed society, cursing it. We needn't be others, but ourselves, taking cognizance of the fact that every culture is unique, distinct, and equal to others- neither inferior nor superior to others. The borrowing, importation and diffusion of certain positive alien cultural traits are worthwhile but when otherwise in most cases, as in Nigeria, it becomes abnormal and crazy. Thus, relegating and bidding extinction of our indigenous cultures which should not be. If the media live up to their expectations, peers and religion as well as the society will only complement the socialisation processes of returning our new generation(s) to our prestigious cultures rather than pursing shadow culture(s) [14]. Then, the family and the school would finish up the remaining task, while playing their cards well within their own respective jurisdiction $[14,17,18]$.

Artificial beauty and fashion contest rules on the continent now. Nude dressing is not African/Nigerian. Immodesty in all regards including dressing, more by women and young ladies, is gradually becoming the more appreciated and valued African dress code. Premarital sex, prostitution, lesbianism and promiscuity, among others, have become the order of the day too. Agriculture, the base of every nation's wealth economy, is grossly abandoned and neglected, resulting to food shortage, hunger/starvation, underdevelopment, economic recession and what have you [17]. Dibie notes, the crazy inherent ways of living of the Westerners seem to have crept most into Nigeria like no other Black nations. Their cultures are rapidly submerging our prestigious cherished indigenous cultural norms, values, traditions, customs and morality. Pervasive socio-cultural, religious, political, economic and educational decadence and laxity have taken precedence in our contemporary society [17].

In the same vein on indigenous culture erosion, Robert [19] poetically writes,

Who becomes the owner of our treasures?

Our fertile land is now deserted by many for her unfertile mates

Our decorated invaluable cultures, deserted

By many for the uncultured

Our mother-tongue, silenced for the aliens

Our treasures are totally robbed off [lines 1-6 stanza 1].

Where are our ancient treasures?

Instead of procreation, we bomb them

With raw acid-atomic bomb and

Gradual rapid painful rocket launcher bullets of extinction [lines 1013 stanza 2].

Where is our religion? 
Ours had been swallowed by the alien,

Giving her blasphemous damnation,

Dabbing her fetish, juju, false belief system and thereabout [lines 1417, stanza 3].

Our treasures are stormed with thunder and atomic bomb

Planted beneath to explode

Day on, day night, until they are no more [19-21 stanza 4].

The above lines and stanzas describe the present ugly situations of our indigenous cultures in the hands of many and in the face of alien cultures purported to be superior, better, more civilised and truly religious. This fake, baseless, prejudicing conception (message) is spread by the mass media, the indigenous ones more. The poet continues:

\section{Where is our pride now that all run from our treasures?}

Imagine our fertile arts, cultures, customs, values, norms,

Races, religion, literature, languages, philosophy, cosmology

Talents and potentials, vegetation, soil.

Water bodies, government... coveted by many outside

Neglected, rejected and dejected from the alien

\section{All for White lives that worth not ours [stanzas 5-6].}

Following Westernisation cum Western mimicry, Nigerian indigenous socio-cultural norms and values as well as cultures have barely little or no place in the contemporary globalised society, having been westernised and incessantly craving to be westernised by Western imitators and Western masters rhetoricians. This emerging near-general trend is a product of poor cultural orientation, confidence and consciousness, misinformation, neo-colonialism and poor socialisation. It is an ageing scourge that emerged with the advent of colonialism vis-a-vis westernisation, civilisation, globalisation and what have you [5].

Robert and Dibie [5]: we have also lost our African linguistic identity, norms and values. The so-called learned elite and families no longer speak their Mother-tongues. Even if from a dual linguistic home, children of such Nigerians/Africans should be taught their either parent's language no matter what. No English or French child born elsewhere would be taught his/her immediate environment language to the exclusion of their Mother Tongue- French/English [5]. But even professors now pry-up bringing-up their children and wards in/with English Language and Western culture. Only [the Hausa, who mostly believe that a Nigerian who does not understand or cannot speak Hausa is not a Nigerian], the Yoruba, the Tiv, a [very] few Igbo, among a few others, still value their respective indigenous languages. Yoruba are even decreasing greatly in the gesture.

Immorality and unholy living have become the order of the day. Pervasive corruption of all kinds now characterises most African societies because of greed. Embezzlement and misappropriation of funds besides failed leadership, elitism and misrepresentation have crept into our local politics $[2,20]$. There is no accountability in both private and public institutions anymore. Religious groups are even more corrupt now than other groups. The religious elite (leaders, both fake and genuine) have become agents of extortion of the 'ordinary' man. Even the little of those who lack is exploited as religious members by their leaders. Why won't the most wretched too starve themselves just to give alms to their religious leaders, when that is the basis for almost everything therein, including funeral? Most church leaders often simply reject some of their dead members because such dead 'owe' the church some dues, thus deny them the supposed rites. If the media have been criticising this trend, it would have since been dropped by at least most of these leaders consciously or unconsciously. This is where the press (media) have failed the common citizens who are why they are there.

Furthermore, Robert and Dibie [5] warn, It is high time we collectively stopped or curbed the incessant emerging contemporary trends of gross abuse, negligence, dabbing and endangerment of and attrition/extinction bids to our precious indigenous cultures, especially by the elite and bourgeois classes [and the media] of our Nigerian society. All these sprawl from the extreme crazy quest for modernism, civilisation and Westernism, pride, Christianity and Islam, globalisation and so on at the expense of our cultures, our rich heritage and indigenous assets. For example, it is regrettable and unfortunate that even the children of some professors, dons and other 'big guns' cannot say a word in their mother-tongues talk more of understanding them.

Mimiko argues, the social fabric was completely devastated and a new culture of violence was implanted. Traditional African systems of conflict resolution were destroyed and, in their places, nothing was given, the democratic process, rudimentary thought, it was, but with great potential as accompanies every human institution, was brutally uprooted and replaced by the authoritarianism of colonialism. A new crop of elites was created, nurtured, and weaned on the altar of violence and colonialism armed with the structures of the modern state to continue to carry out the art and act of subjugation of the mass of the people in the service of colonialism [21].

The above is lent credence to by Kasongo [22], who posits that one could infer that when westernisation was imported to African countries, the hidden side of modernism was materialist interest. The colonial factor was essential to the understanding of the process of Westernisation in Africa itself. The holistic distortions of the hitherto well organised African societies in every sphere of life point to the depth and effectiveness of colonisation in the process of westernising African societies and their culture. The political effects, he notes, include:

(i) Distortions of natural boundaries without due recourse to antecedent institutions and cultures;

(ii) Submerged and dismantled indigenous institutions, including traditional institutions, and, in its place, a foreign rule was established;

(iii) Introduction of Westminster liberal democracy, which does not just work in Africa. It is not that Africa did not have its own pattern of democracy before the imposition of liberal democracy but that typical democracy in Africa and its processes were submerged by westernisation.

Dare queries: What is the effect of embracing Western democracy on Africa? A lot of people will say it is the right way to go as it creates opportunities to participate in affairs, that liberal democracy promotes development. Should democracy be defined and contextualized on the principle of or rather than substance? Is it not evident that Africa is not able to do business with liberal democracy? Is it compulsory to use western type? Is it not feasible and appropriate to arrive at the principle of democracy using African forms, patterns and processes? 
For instance, in Nigeria, in 1993, the country adopted open-secret form in her general elections which was largely acclaimed to be much more successful in terms of voting [but was actually not] [23].

Mimiko contends, the point is that the so-called Kabiyesi syndrome, which has been accorded as an explanation for the shortage of democracy in contemporary Africa, is actually a betrayal of inadequate understanding of the workings of the African traditional political systems. I strongly dispute this proposition as unhistorical and therefore invalid in the context of Africa. Our hypotheses is that in the epoch before contact between European and Africa, the latter not only developed relatively advanced state structures, but that emergent pre-colonial African states also had "sophisticated systems of political rule" with strong democratic foundations. I argue that the basis of the advertised inability of these societies to sustain democracy in contemporary (post-colonial) times could not have consisted in the absence of a democratic culture on their part. Rather, it is the residue of constraints that were attendant upon imperialism, which has been the dominant experience of the African peoples since the fourteenth century- defined most profoundly by slavery, colonialism, neocolonialism, and their handmaiden, military governance [21].

Economically, local economies have been relegated, abused and dabbed. The economy is tailored by the tenets of Western economy. Our economy is exploited by the bourgeoisie. Ours, they plundered and still plunder [23-25]. The drastic shift from agriculture, production mode and entrepreneurship (local enterprises), resulting to food crisis, economic melt-down, hunger and starvation; and the change from communalism to capitalism and neo-liberalism are a product of (neo) colonialism and westernisation [14,26,27].

\section{Conclusion}

The journey of the Nigerian media in the transformation of indigenous cultures is currently nothing to write home about. They have resorted to promoting, developing and emphasising western culture, in its entirety, relegating and dabbing ours, theirs too. It is until they change orientation and do the right thing, promoting, developing and emphasising our indigenous cultures that they can be duly transformed to deserved standard with their supposed prospects and potentials harnessed. The task lies majorly with the mass media. Our media too can transform our indigenous cultures like those of Asia (Asian media's place in the Asian Tigers and what is termed Asian magic), Japan, Germany, China, India, South America and such others, that were erstwhile nowhere until their media brought for them uneven breakthrough, harnessing, developing, promoting, utilising and transforming their indigenous cultures respectively. And, the government and the citizenry must duly support the media for this enormous task/goal to be realised and sustained continuously for ever.

\section{Recommendations}

In view of the foregoing, the following recommendations are made:

- The media must change orientation. There is the dire need for attitudinal change, both on the part of the press, the government and the citizenry.

- We must borrow from foreign cultures. But we cannot swallow without discrimination whatever foreign cultures have to offer [25]. Rather, there should be culture-blending, reformation and transformation.

- There is the dire need for recruiting and training enough cultural journalists to take up this crucial task. The media should challenge the biased and prejudiced perception and ideology of both Westerners and their like Nigerians about their indigenous cultures, while at same time criticising the bad aspects of the indigenous culture towards betterment.

- Our traditional systems and cultures must be made the foundation and centre of our development process, which should be championed/shouldered by the media, their nature and forms notwithstanding.

- The media, through their image-making and development functions, should develop and promote our cultures for economic development and socio-cultural liberation.

- Cultural journalists should always examine foreign cultural media contents, sieve and throw the chaff.

- All other agents of socialisation, particularly the family (parents), the school, peer and religious groups must actively rise to the challenge, towards checking media excesses.

The government too should rise to this trend by correcting the media and putting them on right paths. Programmes on indigenous cultures should be sponsored by the government without majorityminority sentiments. More indigenous cultural studies should be evolved and practically studied at schools from primary to tertiary levels.

\section{References}

1. Ajala VO (1991) Public relations: In search of professional excellence. Ibadan Afrika-Link Books.

2. Chikaan GJ, Ahmad IJ (2011) Mass communication for beginners. Makurdi Azaben Publishers.

3. Sambe JA (2005) Introduction to mass communication. Ibadan: Spectrum Books Ltd.

4. Bittner JR (1989) Mass communication: An introduction. Prentice Hall.

5. Robert OS, Dibie GA (2015) The imperative of effective socialisation towards sustaining indigenous cultures in Nigeria. IIARD International Journal of Philosophy and Cultural Studies.

6. Prah KK (2009) African languages, African development and African unity Centre for Black and African Arts and Civilisation (CBAAC) Organized Public Lecture, Nigeria.

7. Uyo AO (1987) Mass communication classification and characteristics. New York: Ciritetis International.

8. Oyowole AA (2013) Youths and conflict: The role of the media. In: Idebi SKO Madaki WM (eds.) An integrated approach to communication principles and practice. Abuja: Cobweb Book Publishers.

9. Isa M (2005) Culture and the media: An overveiw. In: Yusuff JB (ed.) Culture and the media in Nigeria. National Institute for Cultural Orientation, Abuja.

10. Obasanjo O (1992) Elements of democracy. Abeokuta: ALF Publication.

11. Anyaegbunam N (2005) The media and cultural orientation. In: Yusuff JB (ed.) Culture and the media in Nigeria. National Institute for Cultural Orientation, Abuja.

12. Allimi T (2005) Cultural journalism in Nigeria. In: Yusuff JB (ed.) Culture and the media in Nigeria. National Institute for Cultural Orientation, Abuja.

13. Chikaan GJ (2013) Broadcasting and the broadcast media in Nigeria. Makurdi: Eagle Print.

14. Robert OS, Besong EN, Dibie GA (2015) Retracing our socio-cultural norms/ values for a better African society. Int J Human Soc Sci 2: 1-5.

15. Ndimele, Orru MH (2004) Globalizations and large languages as a threat to cultural and historical small Nigerian languages: the way forward. $10^{\text {th }}$ annual conference of ANLAT, Aba.

16. Nwauzor AA (2014) Changing values in contemporary Nigeria. Educational Research International 3: 103-111. 
Citation: Simon RO, Ndoma BE (2016) Nigerian Media and Indigenous Cultures Transformation: The Journey So Far. J Mass Communicat Journalism 6: 317. doi: 10.4172/2165-7912.1000317

Page 8 of 8

17. Besong EN (2016) Poets perspectives on trends plaguing contemporary Nigeria: A focus on selected poems of Robert OS, Dibie GA and Eze CC.

18. Dibie GA (2016) Implications of fake religious practices and western cultural mimicry in Nigeria. Journal Media and Culture 1: 1-5.

19. Edobor RIO (2008) The school: A social institution and bureaucratic organisation. In: Aluede ROA, Omeregie EO (eds.) Sociology of education. Ekpoma: Alltime Publishing Company.

20. Schaefer RT (2005) Sociology in modules. McGraw Hill.

21. Mimiko NO (2010) Would Falola frustrations suffice? Traditional, governance challenges and the prospects of change in Africa. In: Niyi A (ed.) Toyin Folola: The man, the mask, the muse. North Carolina: Carolina Academic.

22. Kasongo K (2010) Impact of globalization on traditional African religion and cultural conflict. Journal of Alternative Perspectives in the Social Sciences 2: 309-322.

23. Dare A (2010) The effects of western civilization and culture on Africa. Afro Asian Journal of Social sciences 1: 1-2.

24. Ojebode A (2003) Radio as a development communication medium. In: Soola EO (ed.) Communicating for development purposes. Ibadan: Kraft Books Ltd.

25. Okere T (1987) Igbo culture.

26. Taiwo O (1988) Man and culture. In: Olusanya PO, Olumode L (eds.) Readings in introductory sociology. John West Publications Ltd.

27. Uhuo J (1994) Ukawu: The people, cultures and political economy. Ibadan: University Press. 